JSIP: Jurnal Studi Ilmu Pemerintahan

Volume 3, No 1 Februari 2022

ISSN: 2722-7405

\title{
PERAN HUMAS DPRD SEBAGAI SUATU SISTEM DAN FASILITATOR PUBLIK (STUDi PADA DPRD KaBUPATEN BIMA)
}

\author{
Mas'ud $^{1}$, Haeril ${ }^{2}$ \\ 1,2, Program Studi Ilmu Pemerintahan, Sekolah Tinggi Ilmu Sosial dan Ilmu Politik (STISIP) Mbojo Bima, \\ Indonesia \\ Email:amrin5172@gmail.com
}

Kata Kunci:

Humas, sistem ${ }^{1}$, Fasilitator publik ${ }^{2}$, Lembaga Legislatif ${ }^{3}$.

\begin{abstract}
Article Info
Keyword:

Public Relations ${ }^{1}$,

Public Facilitator ${ }^{2}$,

Legislative

Institution ${ }^{3}$.

Abstract: The urgency of this research is to describe the ability of Public Relations as a system and public facilitator for the Bima Regency DPRD in creating accountability and transparency of performance, as well as a positive image during public trust in the Government, especially in the Legislative Institution. This study used descriptive qualitative method. The location of this research is in the Bima Regency DPRD Office. The subjects of this study were selected through purposive sampling technique. The results of the study indicate that the task of Public Relations is a system to establish functional relationships with the public, especially in transforming information (transparency of information and accountability) to the public related to the performance of the DPRD Bima Regency. The leading public relations officer to create, build, improve and maintain the image of the DPRD in public, thereby generating public trust and support for the DPRD's institutional policies. In addition, Public Relations is also present as a public facilitator, to accommodate ideas or aspirations that are found from problems that arise in the community, to be taken into consideration for the implementation of the upcoming DPRD. In this case, all public information is collected later and mapped based on the main problem to be given to the leadership and members of the Bima Regency DPRD in accordance with their duties based on the DPRD's completeness.
\end{abstract}

Abstrak: Urgensi penelitian ini adalah untuk mendeskripsikan kemampuan Humas sebagai sebuah sistem dan Fasilitator publik bagi DPRD Kabupaten Bima dalam menciptakan akuntabilitas dan transparansi kinerja, serta citra positif di mata publik di tengah degradasi kepercayaan masyarakat pada Pemerintah terutama pada Lembaga Legislatif. Penelitian ini menggunakan metode deskriptif kualitatif. Lokasi penelitian ini berada di Kantor DPRD Kabupaten Bima. Subyek penelitian ini dipilih melalui teknik purposive sampling. Dimana hasil penelitian menunjukkan bahwa tugas Kehumasan merupakan sebuah sistem untuk menjalin hubungan fungsional dengan publik terutama dalam mentransformasikan informasi (transparansi informasi dan akuntabilitas) ke Publik terkait dengan kinerja DPRD Kabupaten Bima. Humas terdepan dalam rangka menciptakan, membangun, meningkatkan dan menjaga citra DPRD di hadapan publik, sehingga melahirkan kepercayaan serta dukungan publik terhadap kebijakan DPRD secara kelembagaan. Selain itu Humas juga hadir sebagai fasilitator publik, dalam upaya untuk menampung ide-ide atau aspirasi yang ditemukan dari permasalahanpermasalahan yang muncul di masyarakat, untuk dijadikan bahan pertimbangan untuk pelaksanaan kegiatan DPRD yang akan datang. Dalam hal ini dimana semua informasi publik dihimpun kemudian dan dipetakan berdasarkan pokok permasalahan untuk kemudian diteruskan kepada Pimpinan dan Anggota DPRD Kabupaten Bima sesuai dengan pembidangan tugas berdasarkan alat kelengkapan DPRD.

Article History: Received 2-Desember-2021, Revised 9-Januari-2022, Accepted: 13-Februari-2022 


\section{PENGANTAR}

Citra yang baik merupakan kebutuhan sebuah instansi atau organisasi, maka inilah yang menjadi salah satu tugas yang dilakukan oleh humas sebagai suatu sistem melalui programprogam public relations (Rosyid, 2018). Karena kesuksesan yang diperoleh sebuah instansi itu tidak lepas dari kemampuan devisi humas yang mampu menjalankan perannya dengan baik (Oktarina, 2019).

Dalam melaksanakan tugasnya, Humas sangat lekat dengan fungsi manajemen, yaitu keampuan untuk berperan menciptakan komunikasi, membangun serta menjaga hubungan baik antara organisasi dan publik, baik di dalam organisasi maupun di luar organisasi yang pada akhirnya akan memberikan pengaruh yang cukup besar terhadap keberhasilan sebuah organisasi itu sendiri (Oktarina, 2019). Demikian menurut Nandini (2017), humas atau public relations harus menggunakan komunikasi timbal balik (two ways communications) dalam aktivitas kesehariannya, selain untuk mencapai tujuan organisasi, juga untuk menghindari konflik yang bisa saja terjadi, yang pada akhirnya akan menimbulkan inisiatif yang baik (good will), dan dukungan demi tercapainya citra positif (good image) bagi lembaga/organisasi.

Saaat ini Humas telah menjadi "trend" manajemen modern baik pada organisasi profit maupun non-profit. Trend humas juga hadir dalam alternatif profesi yang dipilih oleh para profesional seperti di lembaga Legislatif Daerah yang membentuk humas sebagai sebuah sistem dalam alat kelengkapan Dewan (Ismayanti, 2016).

Demikian keberadaan Humas pada DPRD Kabupaten Bima. Dewan Perwakilan Rakyat Daerah (DPRD) Kabupaten Bima yang beranggotakan 45 orang, sangat dibutuhkan oleh masyarakat Kabupaten Bima sebagai penyambung aspirasi masyarakat. Sehingga humas harus bisa menciptakan, membangun, meningkatkan, memfasilitasi dan menjaga citra organisasi dikalangan publiknya, serta berkewajiban menumbuh kembangkan hubungan yang harmonis dengan publiknya, agar tercipta citra yang baik (Sujianti, 2018).

Disinilah peran Humas DPRD harus mampu mengamati dan mempelajari tentang hasrat, keinginan-keinginan serta sebagai divisi yang mampu memberikan nasihat dan saran tentang apa yang sebaiknya dilakukan DPRD sebagai Lembaga Pemerintah dalam menampung dan menyelesaikan semua aspirasi masyarakat tanpa adanya pihak-pihak yang dirugikan serta tetap terjalinnya hubungan yang baik dan memunculkan rasa kepercayaan antara publik dengan aparat Pemerintah (Endarta, 2011).

Demikian Nandini (2017) menambahkan, dalam kegiatannya menyebarkan informasi dan komunikasi Humas memerlukan kerjasama dengan pihak lain yaitu diantaranya adalah media. Membangun hubungan yang harmonis dengan media adalah salah satu cara yang harus dilakukan pihak humas dalam usaha mencapai tujuan. Demikian menurut Kusuma \& Paselle (2017), hubungan antara legislatif dan media memang tidak mempunyai hubungan struktural yang mengharuskan adanya keterkaitan secara lembaga. Namun, kedua lembaga ini saling membutuhkan dalam hal membangun hubungan kemitraan. Terutama kemitraan di bidang informasi, komunikasi dan kontrol sosial. Bagi lembaga legislatif hubungan kemitraan dengan media pers ini menjadi penting mengingat fungsi dan peranan pers diperlukan untuk mensosialisasikan berbagai aktifitas lembaga legislatif, baik yang berkaitan dengan fungsi legislasi sebagai pembuat Peraturan Perundang-Undangan, maupun yang berhubungan dengan fungsi kontrol terhadap eksekutif serta fungsi pengawasan terkait pelaksanaan pembangunan.

Untuk itu menjadi penting bagi penulis untuk mendeskripsikan kemampuan Humas sebagai sebuah sistem dan Fasilitator publik bagi DPRD Kabupaten Bima dalam meciptakan akuntabilitas dan transparansi kinerja, serta citra positif di mata publik di tengah degradasi kepercayaan masyarakat Kabupaten Bima pada Pemerintah terutama pada Lembaga Legislatif.

\section{METODE PENELITIAN}

Penelitian ini menggunakan metode deskriptif kualitatif. Lokasi penelitian ini berada di Kantor DPRD Kabupaten Bima, lokasi tersebut sangat strategis dalam melihat studi kasus dan permasalahan yang terjadi. Subyek penelitian ini dipilih melalui teknik nonprobability sampling, dengan menggunakan teknik purposive sampling atau teknik penentuan sampel dengan mempertimbangkan aspek tertentu. Teknik pengumpulan data terdiri atas observasi 
(observation), wawancara (interview), dan dokumentasi (documentation). Setelah data selesai dikumpulkan dengan lengkap dari lapangan, tahap berikutnya yang harus lakukan adalah tahap analisa data. Dalam penelitian ini menggunakan teknik analisa data model interaktif menurut Miles dan Huberman yang terdiri dari dari tiga hal utama, yaitu; reduksi data, penyajian data, dan penarikan kesimpulan/verifikasi..

\section{HASIL DAN DISKUSI}

Dalam menganalisis dan menjelaskan lebih mendalam terkait dengan peran Humas DPRD Kabupaten Bima sebagai sebuah sistem dan fasilitator publik, penulis menggunakan teori sistem milik David Easton dalam mengemukakan fakta-fakta penelitian.

Menurut David Easton dalam Anggara (2013: 25) bahwa Teori sistem adalah suatu model yang menjelaskan hubungan tertentu antara sub-sub sistem dengan sistem sebagai suatu unit (yang bisa saja berupa suatu masyarakat, serikat buruh, maupun organisasi Pemerintah). Menurutnya dalam sistem terdapat hubungan fungsional yang terutama dilandasi oleh beberapa bentuk komunikasi. Kemudian terdapat sub-sub sistem yang satu sama lainnya saling melakukan pertukaran (seperti antara DPRD dengan publik). Kemudian sistem tersebut bisa membuat kode, yaitu menerima informasi, mempelajari dan menerjemahkan masukan (input) kedalam beberapa jenis keluaran (output).

\section{Humas sebagai Suatu Sistem}

Secara kelembagaan tugas Kehumasan di DPRD Kabupaten Bima dijalankan oleh Sub Bagian Humas dan Protokol yang berada di bawah Bagian Persidangan dan Perundang-Undangan pada Sekretariat DPRD Kabupaten Bima. Adapun beberapa program Tahunan yang dijalankan Humas di DPRD Kabupaten Bima, yaitu menerbitkan buku profil Pimpinan dan Anggota DPRD Kabupaten Bima, menerbitkan Buku Memori Tugas DPRD Kabupaten Bima lima tahunan, membuat Banner Profil Alat-Alat Kelengkapan DPRD, menjalin kerjasama kemitraan dengan media massa, cetak maupun online dalam rangka pemuatan berita-berita kegiatan DPRD, mengelola program JDIH untuk penyebarluasan produk hukum DPRD, serta mengelola akun-akun media sosial seperti Facebook, Instagram, dan youtube DPRD Kabupaten Bima untuk penyebarluasan informasi kegiatan DPRD Kabupaten Bima.

Kemudian sebagai bentuk upaya yang dilakukan Humas DPRD Kabupaten Bima dalam menjalin hubungan fungsional dengan publik ialah dengan bekerjasama dengan media-media lokal dalam mentransformasikan informasi (transparansi informasi dan akuntabilitas) ke Publik yaitu, melakukan kerjasama dalam bentuk advetorial pemuatan informasi kegiatan DPRD Kabupaten Bima melalui media massa, melakukan kerjasama langganan koran khususnya cetak dengan media massa, membuat WA Group Mitra Humas DPRD Kabupaten Bima, dimana anggotanya adalah para wartawan media massa yang bertugas di Bima. Kemudian secara rutin mengirimkan press release informasi DPRD Kabupaten Bima kepada media.

Sebagai sebuah sistem Humas juga berupaya menyusunan konsep dan counter issue (berita) yang beredar di masyarakat atau di media massa dengan cepat, kemudian penyiapan naskah kehumasan, penerbitan informasi dan dokumentasi kegiatan DPRD Kabupaten Bima serta mengupayakan pelayanan melalui media center.

Selain itu, media-media yang menjalin kerjasama /kemitraan dengan Humas DPRD Kabupaten Bima untuk kerjasama secara Advetorial dan secara Parlementaria. Kerjasama secara Advetorial dan Parlementaria atau yang lebih dikenal dengan istilah editorial dan advertising ini berkaitan dengan periklanan/informasi sebagai upaya persuasif untuk menginformasikan kerjakerja DPRD Kabupaten Bima lewat media cetak maupun online kepada publik. Adapun kerjasama secara Advetorial dan kerjasama secara Parlementaria dilakukan pada sebanyak 40 media, baik cetak maupun online. Sedangkan media yang menjalin kerjasama dalam bentuk langganan koran sebanyak 28 media cetak.

Pentingnya peran media dalam menunjang pelaksanaan tugas DPRD, khususnya dalam mensosialisasikan berbagai kegiatan dan informasi terkait pelaksanaan tugas DPRD. Menyadari sehingga DPRD Kabupaten Bima selalu terbuka dengan media, dengan selalu merespon apapun informasi yang dibutuhkan terkait pelaksanaan tugas, fungsi dan wewenang DPRD. Karena semua 
kegiatan dan produk politik yang dihasilkan lembaga DPRD Kabupaten Bima tidak akan sampai ke masyarakat tanpa adanya bantuan dari media. Semua informasi dari DPRD disalurkan ke media untuk diteruskan ke masyarakat, tapi sebaliknya dalam mendukung pelaksanaan tiga fungsi DPRD, baik Legislasi, Pengawasan, maupun Anggaran, semua informasi yang diberitakan oleh media menjadi sangat penting sebagai bahan informasi bagi kelembagaan di DPRD untuk ditindaklanjuti.

Salah satu fungsi penting dari Humas sebagai suatu sistem di lembaga DPRD Kabupaten Bima yang notabene sebagai representasi rakyat, adalah melakukan langkah-langkah dalam rangka menciptakan, membangun, meningkatkan dan menjaga citra DPRD di hadapan publik, sehingga melahirkan kepercayaan serta dukungan publik terhadap kebijakan DPRD secara kelembagaan. Dalam konteks itu, selama ini Humas di DPRD Kabupaten Bima selalu berupaya secara maksimal menyajikan informasi tentang berbagai kegiatan dan produk yang dihasilkan oleh DPRD. Kemudian memantau dan merespon opini publik yang berkembang, baik di media massa maupun di tengah-tengah masyarakat yang berkaitan dengan DPRD, kemudian Humas hadir menanggapi permaslaahan dan menyajikan informasi untuk merespon balik opini yang berkembang tersebut, sehingga opini yang berkembang tidak bias dan merusak citra lembaga. Selain itu, Humas juga melakukan koordinasi dan kemitraan yang harmonis dengan semua stakeholder, terutama rekan-rekan media dalam menunjang kerja kehumasan untuk kepentingan terjaganya citra baik lembaga DPRD Kabupaten Bima.

Selanjutnya dalam upaya untuk menampung ide-ide atau aspirasi yang ditemukan dari permasalahan-permasalahan yang muncul di masyarakat, dimana ide-ide atau aspirasi tersebut akan ditampung oleh pihak humas untuk dijadikan bahan pertimbangan untuk pelaksanaan kegiatan yang akan datang. Hal ini menunjukkan bahwa Humas di DPRD Kabupaten Bima telah menjalankan perannya sebagai penasehat ahli. Salah satu peran Humas yaitu sebagai penasehat ahli (Expert prescriber) artinya seorang Humas harus memiliki pengalaman dan kemampuan yang tinggi untuk dapat membantu mencarikan solusi dalam penyelesaian masalah publik.

\section{Humas sebagai Fasilitator Publik}

Humas DPRD Kabupaten Bima juga rutin menerima, dan mempelajari berbagai masukan, saran, dan kritik masyarakat tentang berbagai hal terkait DPRD Kabupaten Bima ini merupakan salah satu fungsi humas sebagai fasilitator publik.

Humas sebagai fasilitator publik dimana semua informasi publik dihimpun kemudian dan dipetakan berdasarkan pokok permasalahan untuk kemudian diteruskan kepada Pimpinan dan Anggota DPRD Kabupaten Bima sesuai dengan pembidangan tugas berdasarkan alat kelengkapan DPRD. Dari informasi tersebut kemudian akan ditentukan langkah tindaklanjut oleh masingmasing alat kelengkapan DPRD untuk merespon permasalahan tersebut. Hasil dari tindaklanjut oleh alat kelengkapan DPRD tersebut selanjutnya akan menjadi bahan informasi untuk diteruskan kepada publik. Walaupun tanpa diketahui luas oleh publik, hampir sebagian kegiatan rapat-rapat di DPRD itu adalah tindaklanjut atau respon Anggota Dewan atas aspirasi atau tuntutan masyarakat yang disampaikan lewat berita-berita di media.

Selain itu, Humas DPRD Kabupaten Bima juga sebagai penghubung antar lembaga Pemerintah (antara DPRD dengan Eksekutif), legislatif dengan lembaga-lembaga non Pemerintah, maupun dengan media, serta masyarakat luas. Dalam pelaksanaannya Humas DPRD Kabupaten Bima juga menggunakan akun Facebook dan Instagram untuk menjalankan perannya dalam mengumpulkan, mengolah dan menyebarkan informasi secara berkala yang berkaitan dengan program/kebijakan, aktivitas dan capaian yang diraih oleh lembaga hingga tanggapan lembaga atas respon, aspirasi dan opini yang berkembang di masyarakat terhadap DPRD Kabupaten Bima. Berikut adalah gambar akun official Facebook dan Instagram milik DPRD Kabupaten Bima.

Dalam menghadirkan fungsi fasilitator publik, Humas DPRD Kabupaten Bima aktif di bidang publikasi, manajemen informasi dan komunikasi. Dimana Humas sangat rutin melakukan publikasi informasi pada media sosial milik DPRD Kabupaten Bima sebagai bentuk transparansi informasi publik. Termasuk yang berkaitan dengan Jadwal harian kegiatan DPRD Kabupaten Bima yang terpublish dengan baik, mulai dari waktu kegiatan, agenda, peserta rapat dan tempatnya.

Namun informasi terkait keigatan DPRD belum sepenuhnya maksimal dilakukan, dikarenakan kurang updatenya informasi dari beberapa akun media sosial milik DPRD Kabuapten 
Bima, selain itu website resmi kelembagaan yang harusnya dijadikan sebagai Media Kempanye dan Publisitas DPRD Kabupaten Bima juga belum maksimal dikelola. Selain itu juga penerbitan berita lewat kerjasama parlementaria yang belum ada jadwal khususnya. Padahal akan sangat bermanfaat bagi publik jika parlementaria bisa terbit secara berkala dan berkelanjutan.

Kemudian Humas juga hadir sebagai Fasilitator Komunikasi yang merupakan elemen penting yang dapat mempengaruhi cara pandang masyarakat terhadap Pemerintah. Humas memiliki peran sebagai fasilitator komunikasi antara pemerintah dan publiknya. Humas di DPRD Kabupaten Bima telah menjalankan perannya sebagai fasilitator komunikasi dengan merancang semua komunikasi apa saja yang dilakukan oleh DPR dan memberikan informasi secara jelas kepada publik agar tercipta pemahaman publik, khususnya pemahaman publik mengenai kegiatan-kegiatan yang dilakukan oleh pihak DPRD Kabupaten Bima.

Peran humas sebagai fasilitator komunikasi dimana humas bertindak sebagai komunikator atau mediator untuk membantu pihak manajemen dalam hal mendengar apa yang diinginkan dan diharapkan oleh publiknya. Sebagai penghubung antara pihak DPRD Kabupaten Bima dengan masyarakatnya agar proses penyampaian informasi mengenai kegiatan-kegiatan yang dilakukan oleh pihak DPRD dapat berjalan dengan lancar maka humas DPRD Kabupaten Bima melaksanakan peran humas dengan menyampaikan informasi ke publik.

Sebagai fasilitator komunikasi publik humas membantu Pimpinan organisasi, baik sebagai penasehat hingga berperan mengambil langkah dalam mengatasi persoalan yang dihadapi secara rasional dan professional. Peran humas sebagai fasilitator proses pemecahan masalah sudah diwujudkan oleh humas DPRD Kabupaten Bima dengan memberikan pelayanan yang baik, menampung aspirasi masyarakat, kritik dan juga saran, kemudian mencari solusi dari permasalahan yang ada. Kemampuan komunikasi menunjukkan bahwa peran humas berkaitan dengan bagaimana teknik humas dalam mengkomunikasikan informasi ke publiknya. Alur kegiatan kehumasan di DPRD Kabupaten Bima dengan mengetahui terlebih dahulu apa yang menjadi keinginan masyarakat, kemudian dirapatkan terlebih dahulu dengan yang bersangkutan, baru dibuatkan rencana kedepannya untuk diinformasikan kepada masyarakat jika tuntutan atau aspiranya sudah didengar oleh pihak DPRD dan akan direalisasikan kedepannya.

Seperti halnya tuntutan massa aksi Laskar Tani Donggo Soromandi yang menuntut BUMD PD. Wawo untuk menyerap produksi pertanian masyarakat Kabupaten Bima. Untuk merespon itu Humas DPRD Kabupaten Bima merilis berita tersebut di media dan memposting diakun Facebook resmi milik DPRD Kabupaten Bima. Kemudian dengan cepat Anggota DPRD Dapil III membuat pernyataan sikap merespon tuntutan masyarakat yang ditanda tangani diatas materai dan dibacakan dihadapan massa aksi.

Pernyataan sikap tersebut dibuat sebagai tanggungjawab untuk diperjuangkan dan dilaksanakan sesuai kapasitas, fungsi dan wewenang sebagai Anggota DPRD Kabupaten Bima Dapil III yaitu Kecamatan Donggo, Soromandi, dan Tambora. Namun saat ini tidak bisa dipungkiri bahwa Humas DPRD Kabupaten Bima belum sepenuhnya mampu mengontrol isu-isu negatif tentang lembaga yang berkembang dimasyarakat. Dikarenakan adanya media abal-abal yang memberikan pemberitaan dengan narasi yang sebenarnya tidak sesuai dengan fakta dilapangan.

\section{KESIMPULAN}

Tugas Kehumasan merupakan sebuah sistem untuk menjalin hubungan fungsional dengan publik terutama dalam mentransformasikan informasi (transparansi informasi dan akuntabilitas) ke Publik terkait dengan kinerja DPRD Kabupaten Bima. Humas terdepan dalam rangka menciptakan, membangun, meningkatkan dan menjaga citra DPRD di hadapan publik, sehingga melahirkan kepercayaan serta dukungan publik terhadap kebijakan DPRD secara kelembagaan. Selain itu Humas juga hadir sebagai fasilitator publik, dalam upaya untuk menampung ide-ide atau aspirasi yang ditemukan dari permasalahan-permasalahan yang muncul di masyarakat, untuk dijadikan bahan pertimbangan untuk pelaksanaan kegiatan DPRD yang akan datang. Dalam hal ini dimana semua informasi publik dihimpun kemudian dan dipetakan berdasarkan pokok permasalahan untuk kemudian diteruskan kepada Pimpinan dan Anggota DPRD Kabupaten Bima sesuai dengan pembidangan tugas berdasarkan alat kelengkapan DPRD. 


\section{REFERENSI}

Anggara, S. (2013). Sistem Politik Indonesia (Vol. 1, No. 1). Cv Pustaka Setia

Black, A. James Dan J. Champion, Dean, 2009. Metode \& Masalah Penelitan Sosial. Bandung. Refika Aditama. Cetakan Keempat.

Endarta, A. S. (2011). Peran Humas Dprd Surakarta Dalam Membangun Hubungan Dengan Media Tahun 2011 (Doctoral Dissertation, Universitas Sebelas Maret).

Easton, D. (1984). Kerangka Kerja Analisa Sistem Politik. Jakarta: Bina Aksa.

Ismayanti, R. (2016). Peranan Hubungan Masyarakat Dalam Pelayanan Publik Di Dewan Perwakilan Rakyat Daerah Kabupaten Sinjai (Doctoral Dissertation, Universitas Negeri Makassar).

Kusuma, A. R., \& Paselle, E. (2017). Peran Humas Sekretariat Dprd Dalam Menjalin Hubungan Sinergis Antara Media Dengan Dprd Kabupaten Bulungan. Jurnal Administrative Reform (Jar), 3(4), 441-451.

Muhammad Idrus. 2009. Metode Penelitian Ilmu Sosial "Pendekatan Kualitatif Dan Kuantitatif" Edisi Kedua. Jakarta. Erlangga.

Nandini, R. F. (2017). Efektivitas Media Relations Dalam Meningkatkan Citra Positif Dewan Perwakilan Rakyat Daerah Kota Jambi (Studi Deskriptif Analisis Efektivitas Media Relations Dalam Mempublikasikan Program Kerja Guna Meningkatkan Citra Positif Dprd Kota Jambi) (Doctoral Dissertation, Perpustakaan).

Oktarina, A. (2019). Strategi Public Relations Dalam Mempertahankan Citra Positif Dprd Kabupaten Rejang Lebong (Doctoral Dissertation, Iain Curup).

Rosyid Al Habib, D. E. R. I. L., \& Suratman, B. (2018). Peran Humas Dalam Meningkatkan Citra Positif Pada Lembaga Pemerintahan Dprd Kabupaten Nganjuk. Jurnal Administrasi Perkantoran, 6(2).

Sujianti, I. N. (2018). Strategi Humas Dalam Meningkatkan Citra Positif Dprd Kota Malang (Studi Pada Humas Sekretariat Dprd Kota Malang) (Doctoral Dissertation, University Of Muhammadiyah Malang).

Sugiyono. (2014). Metode Penelitian Kuantitatif, Kualitatif, Dan R\&B. 